\title{
Instrumental Neutron Activation Analyses in the Ancestral Caddo Territory
}

Robert Z. Selden Jr. Heritage Research Center, Stephen F. Austin State University

Follow this and additional works at: https://scholarworks.sfasu.edu/ita

Part of the American Material Culture Commons, Archaeological Anthropology Commons, Environmental Studies Commons, Other American Studies Commons, Other Arts and Humanities Commons, Other History of Art, Architecture, and Archaeology Commons, and the United States History Commons

Tell us how this article helped you.

This Article is brought to you for free and open access by the Center for Regional Heritage Research at SFA ScholarWorks. It has been accepted for inclusion in Index of Texas Archaeology: Open Access Gray Literature from the Lone Star State by an authorized editor of SFA ScholarWorks. For more information, please contact cdsscholarworks@sfasu.edu. 
Instrumental Neutron Activation Analyses in the Ancestral Caddo Territory

Creative Commons License

(c) $)(1)$ (9)

This work is licensed under a Creative Commons Attribution-NonCommercial 4.0 International License 


\title{
InSTRUMENTAL NEUTRON ACTIVATION ANALYSES IN THE ANCESTRAL CAdDO TERritory
}

\author{
Robert Z. Selden
}

\section{Revisiting the Caddo INAA Dataset}

In an attempt to better comprehend the geochemical composition of ceramic sherds across the traditional Caddo landscape, the INAA results for 1192 sherds from 164 sites are employed within this discussion (not included in this sample are sherds from sites recovered in central Texas). After assembling the dataset, two tables were used-one with geochemical data, one with site data-to catalog the sample. The shell and bone-tempered sherds were noted, but the calcium correction (see Steponaitis et al. 1996:559) was only applied to the $4 \%(n=47)$ of samples known to be shell-tempered (see Figure 1).

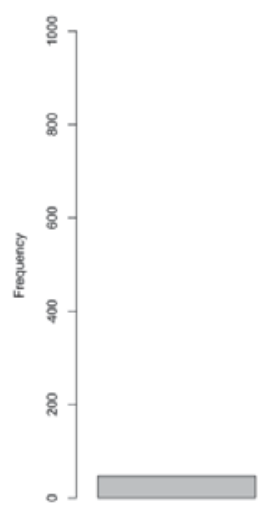

Shet

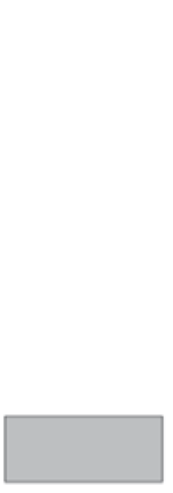

Bone

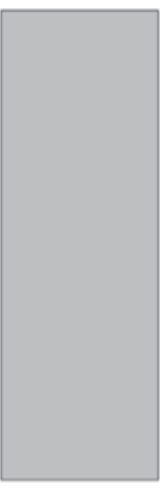

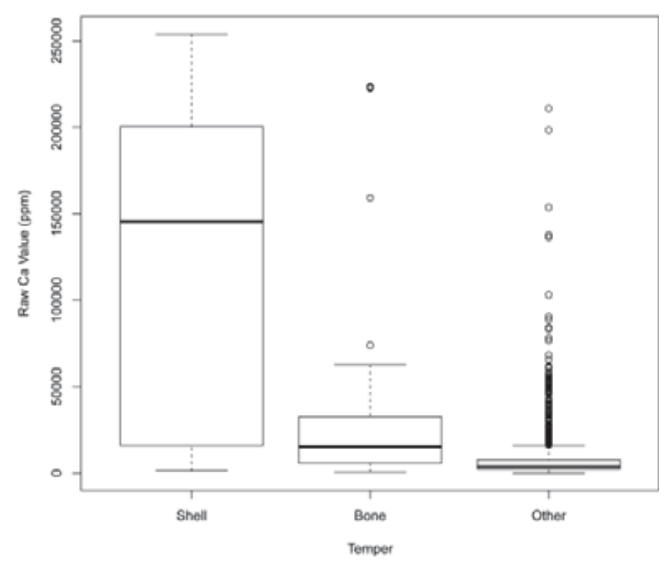

Figure 1. Frequency and uncorrected Ca values for shell, bone and other tempers in the Caddo INAA dataset.

The calcium correction was applied to these 47 sherds in version 2.15 .2 of $\mathrm{R}$, after which those sherds were recombined with the bone and other-tempered sherds, and the log-10 of each element was calculated, adding a value of one to each sherd/element in the database, effectively replacing all missing values with a zero. Subseqently, the Getis-Ord Gi* statistic in ArcGIS10 was employed to calculate a z-score for each log-10 value, illustrating the spatial distribution and z-score value for each element using the formula:

$$
G_{i}^{*}=\frac{\sum_{j=1}^{n} w_{i, j} x_{j}-\bar{X} \sum_{j=1}^{n} w_{i, j}}{\sqrt{\frac{\left[n \sum_{j=1}^{n} w_{i, j}^{2}-\left(\sum_{j=1}^{n} w_{i, j}\right)^{2}\right]}{n-1}}}
$$

where $x_{j}$ is the attribute value for feature $j, w_{i, j}$ is the spatial weight between feature $i$ and $j, n$ is equal to the total number of features and: 


$$
\begin{gathered}
\bar{X}=\frac{\sum_{j=1}^{n} x_{j}}{n} \\
S=\sqrt{\frac{\sum_{j=1}^{n} x_{j}^{2}}{n}-(\bar{X})^{2}}
\end{gathered}
$$

The $G_{i}^{*}$ statistic is a z-score so no further calculations are required (ESRI 2012).

Following the calculation of log-10 values for each element, these data were then used to calculate the deterministic statistic of inverse distance weighted (IDW) in ArcGIS10 for each element to better illustrate whether discrete geochemical signatures exist close to one another, or in the same location (see Mitchell 2005; ESRI 2004). Pulling from these results, the geographic illustrations seem to clarify much, but can also be used to clarify and expand upon assertions made in previous analyses. For instance, the geographic distribution of chromium (Cr) appears to support Ferguson's (2010:16-17) assertion regarding an apparent gradient in the Sabine River drainage, an observation which might now be extended to all but the Red River drainage in East Texas. What follows are the geographic illustrations created through this process, which document the spatial diversity and variability for each of the reported elements (Figures 2-10).

\section{Summary and Conclusion}

INAA sample sizes must be increased within sites and from new sites to further current dialogues regarding possible ceramic provenance determinations within the ancestral Caddo territory. In order to achieve a confident level of statistical significance, a minimum of 30 sherds should be submitted for INAA from each site. This makes it possible to create a site-specific correspondence matrix from which an exploration of statistical similarities and differences can assist in the identification of clays found in the ceramics used at each site.

The chemical maps presented here represent an important new analysis of the Caddo INAA database. The results of this analysis illustrate that the chemical composition of ceramics associated with ancestral Caddo populations were diverse and highly variable across East Texas and surrounding states, hinting at the potential successes in ceramic provenance identifications for more robust $(>30)$ samples of sherds from sites within this region. 


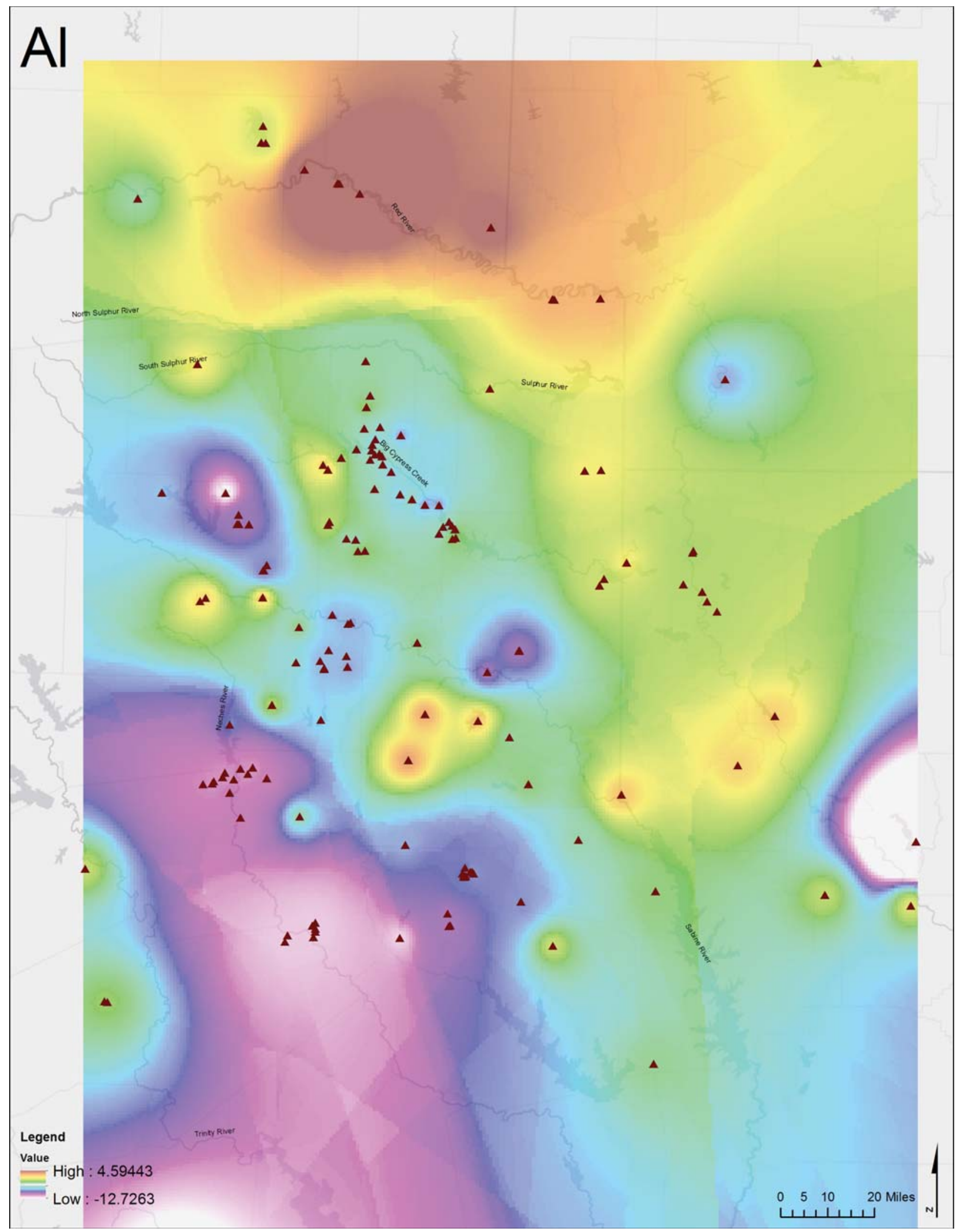

Figure 2. Al presence in data set. 

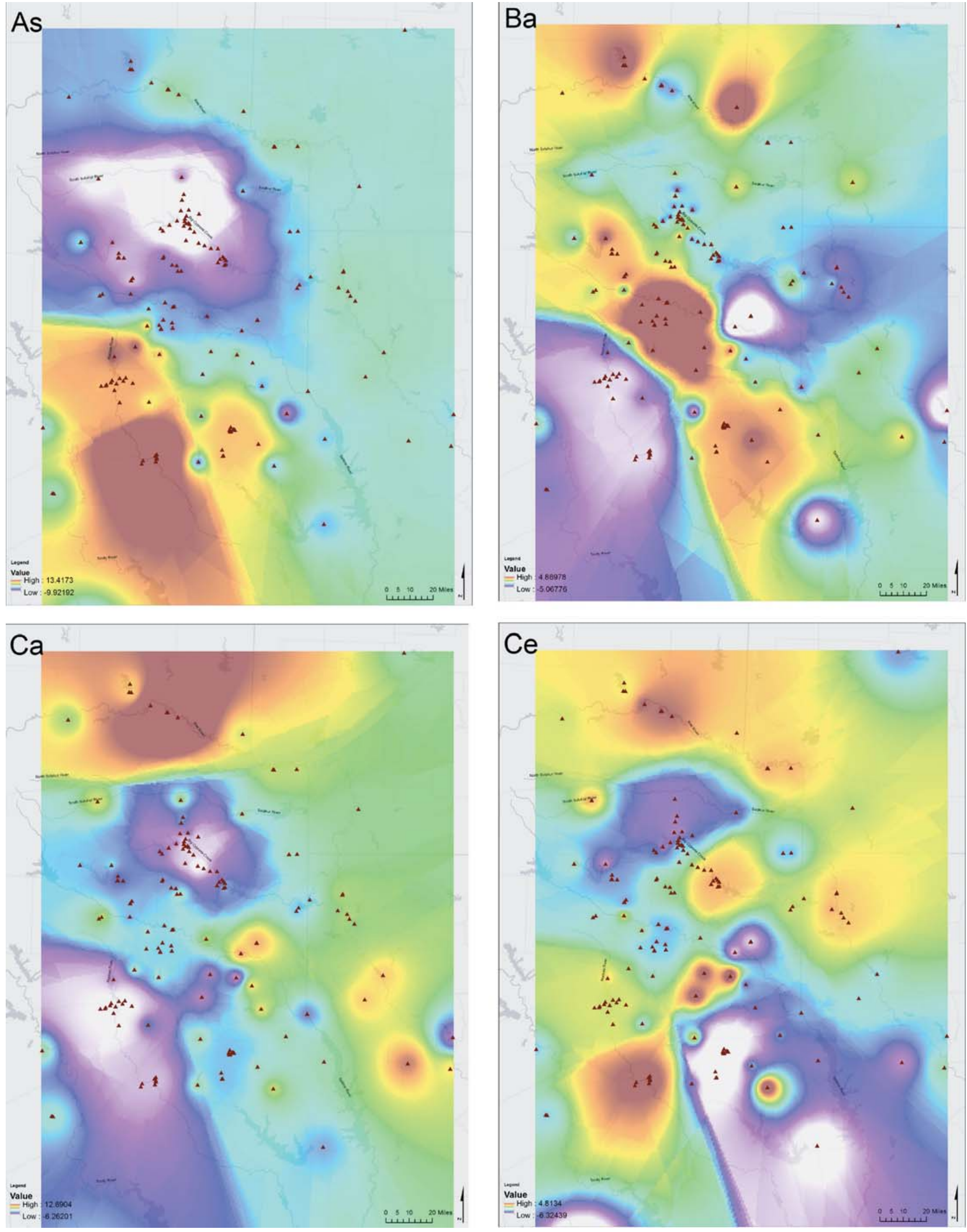

Figure 3. $A s, B a, C a$, and $C e$ presence in data set. 

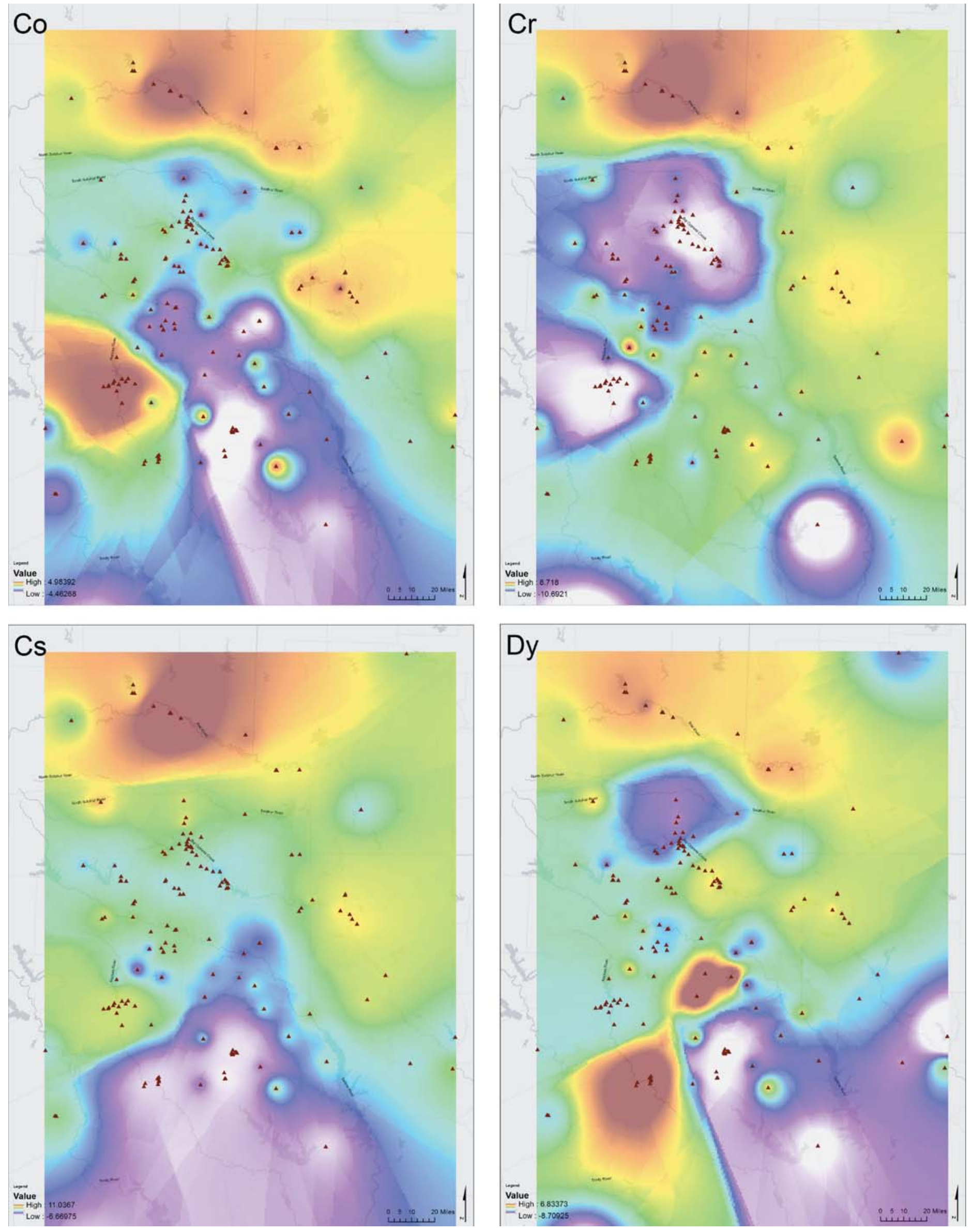

Figure 4. Co, Cr, Cs, and Dy presence in data set. 


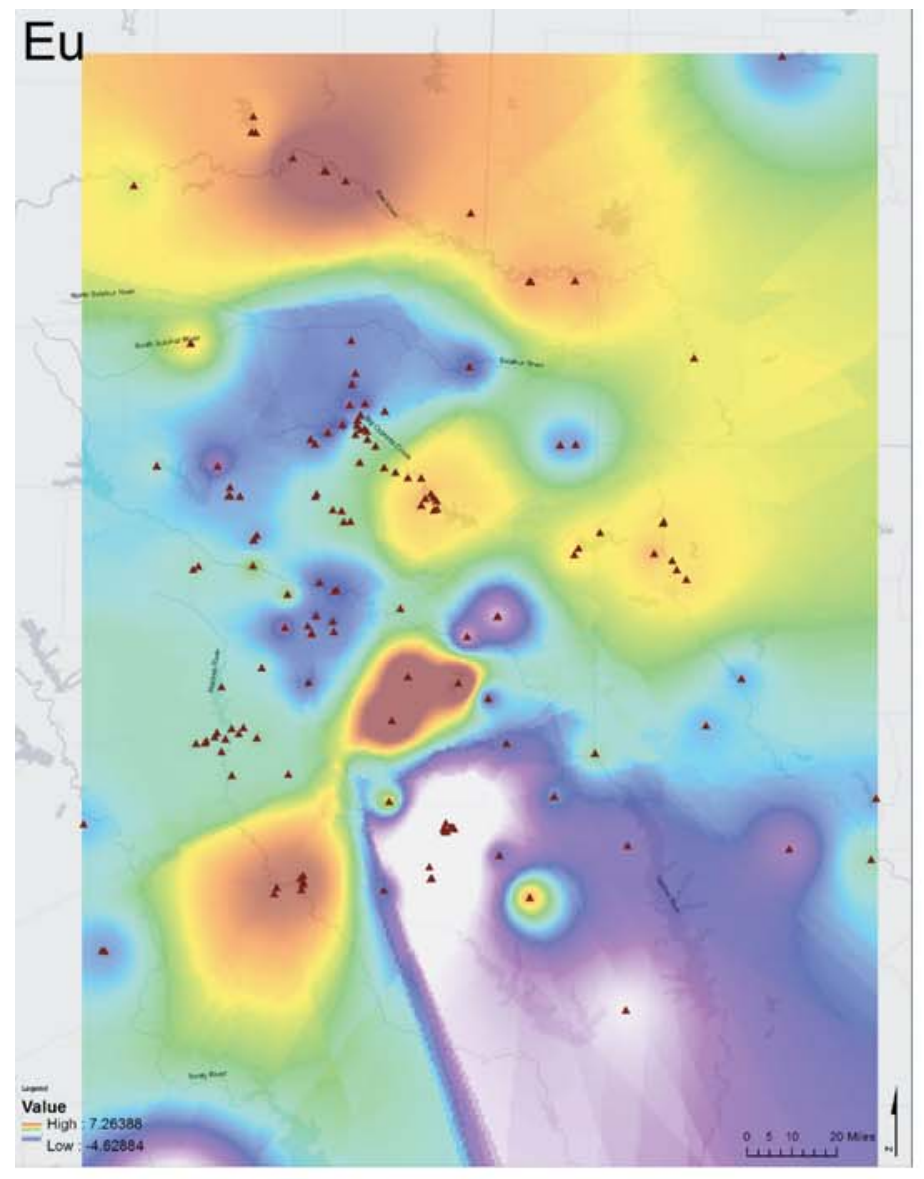

$\mathrm{Fe}$

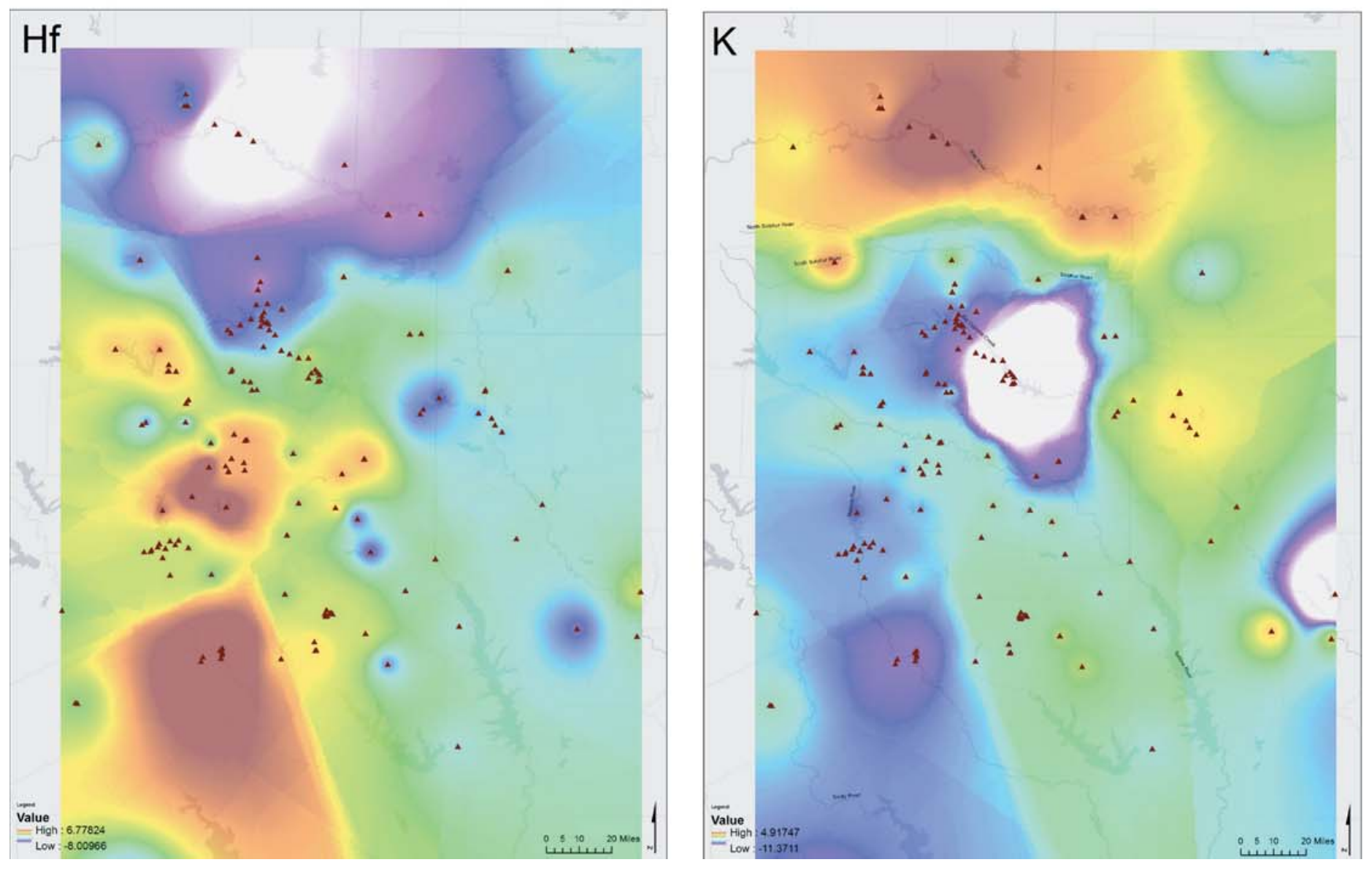

Figure 5. $E u, F e, H f$, and $K$ presence in data set. 

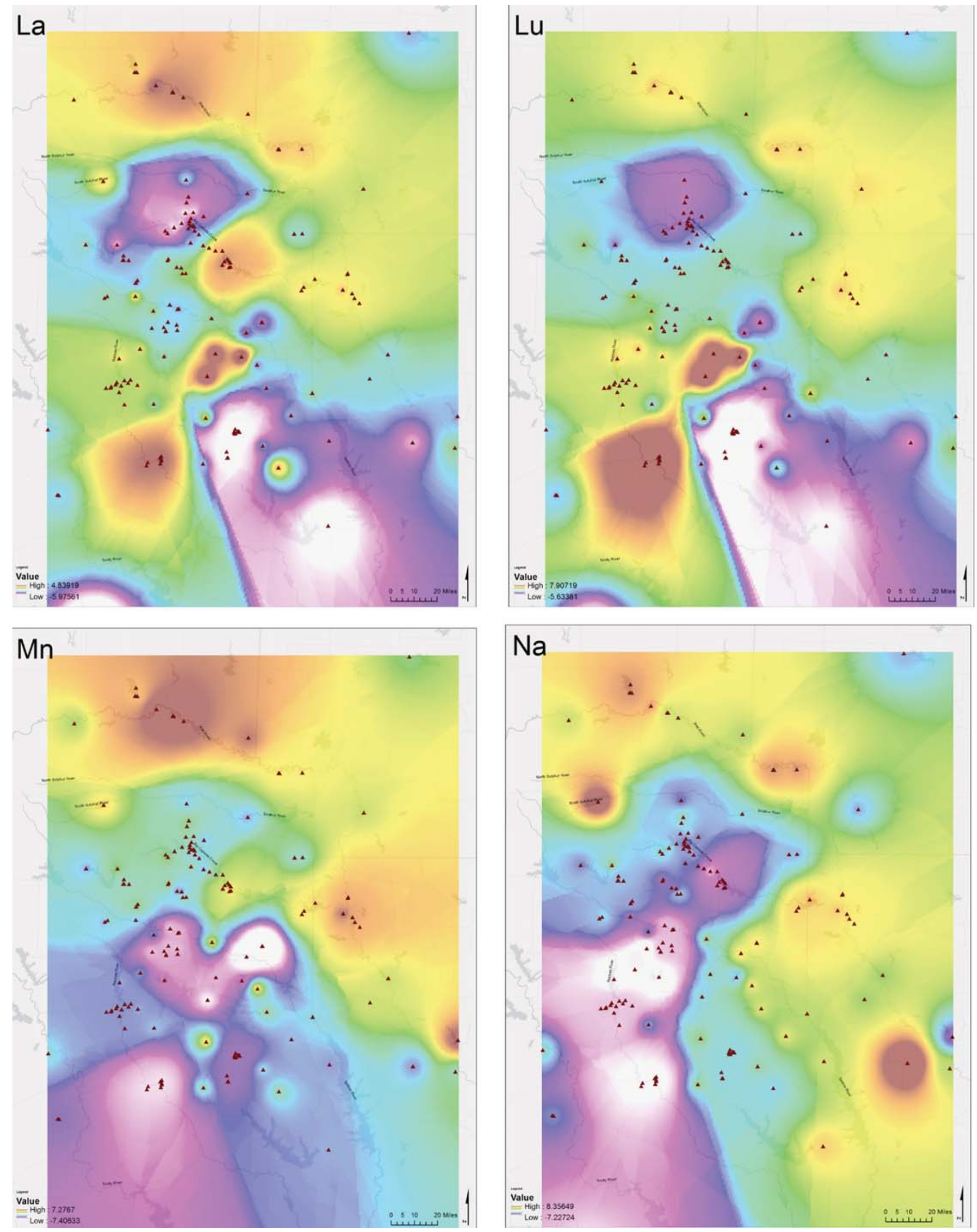

Figure 6. $L a, L u, M n$, and $N a$ presence in data set. 
$\mathrm{Nd}$
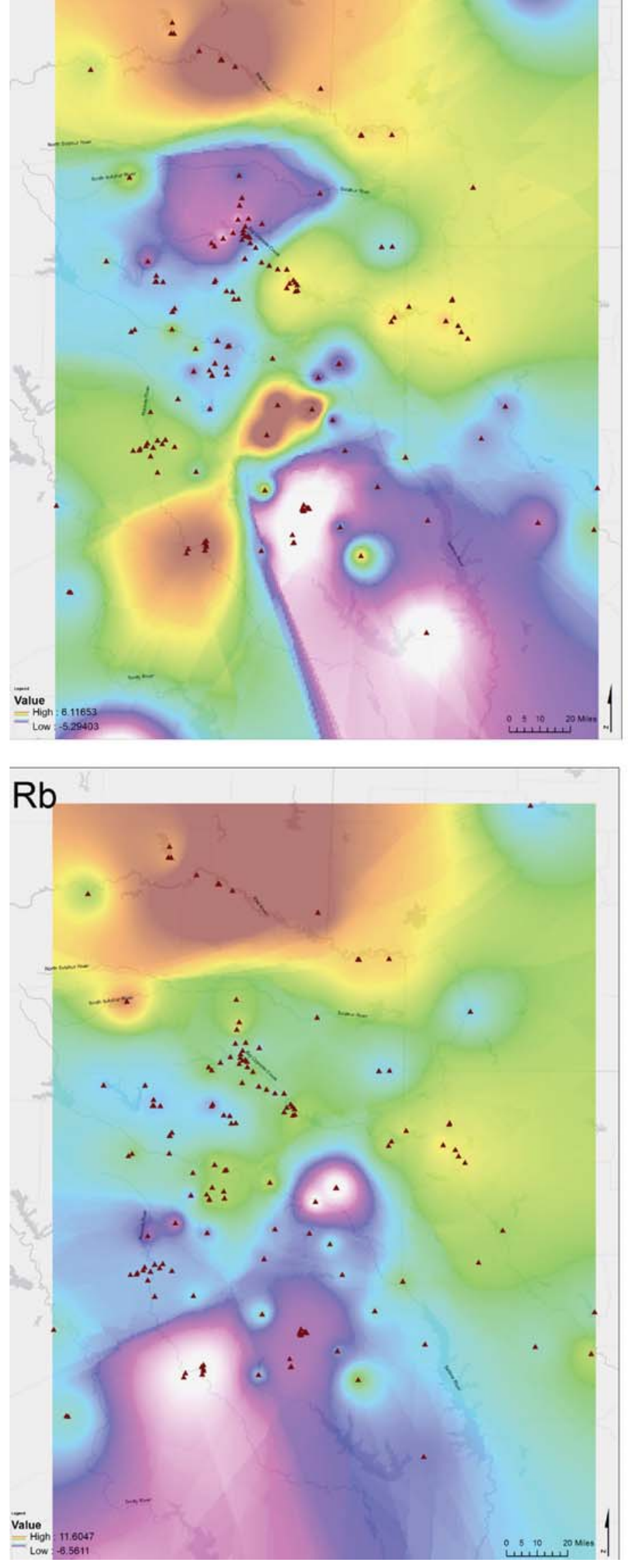

$\mathrm{Ni}$
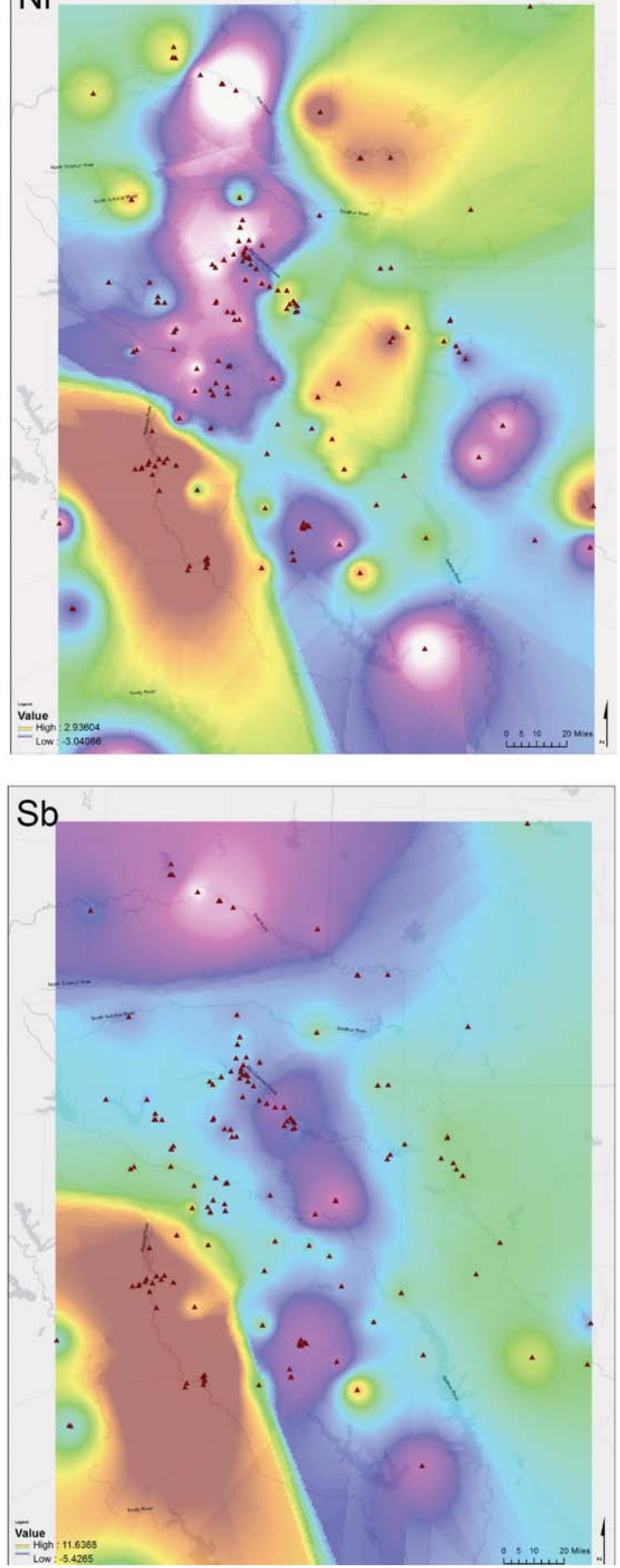

Figure 7. $N d, N i, R b$, and $S b$ presence in data set. 
Sc
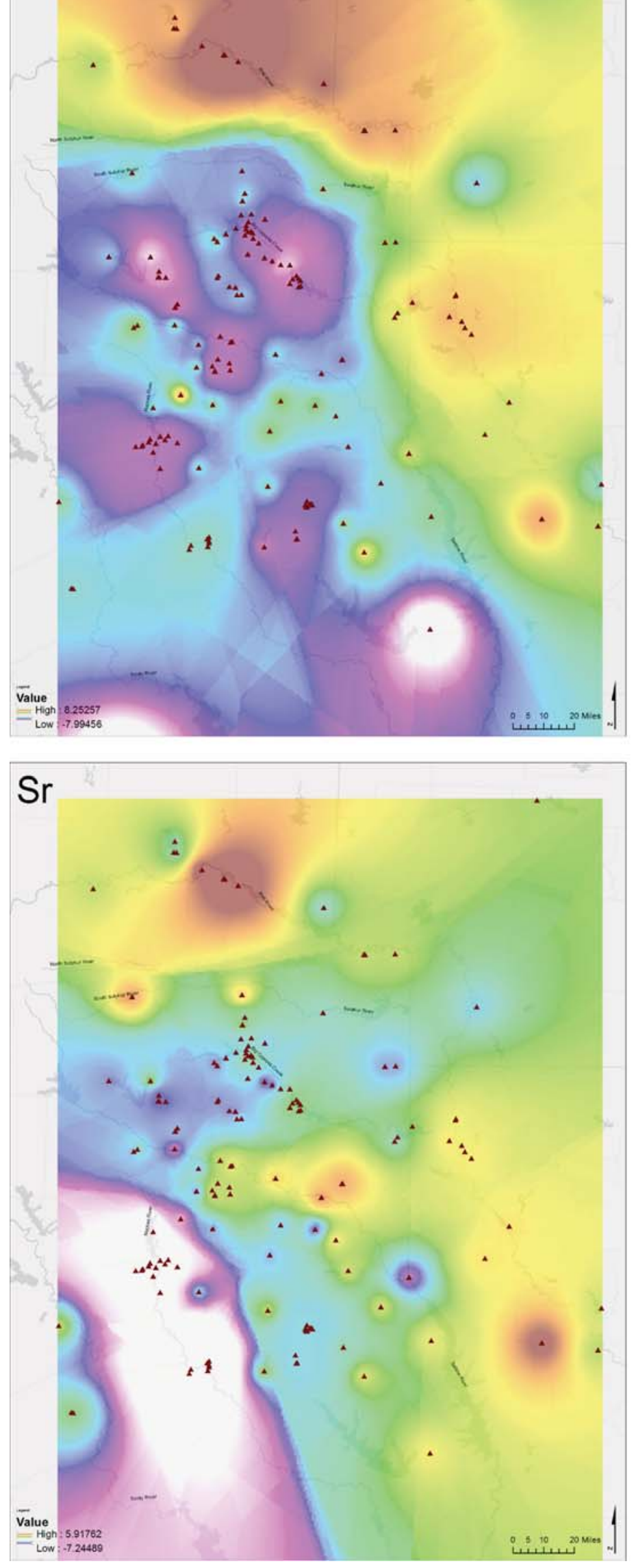

$\mathrm{Sm}$
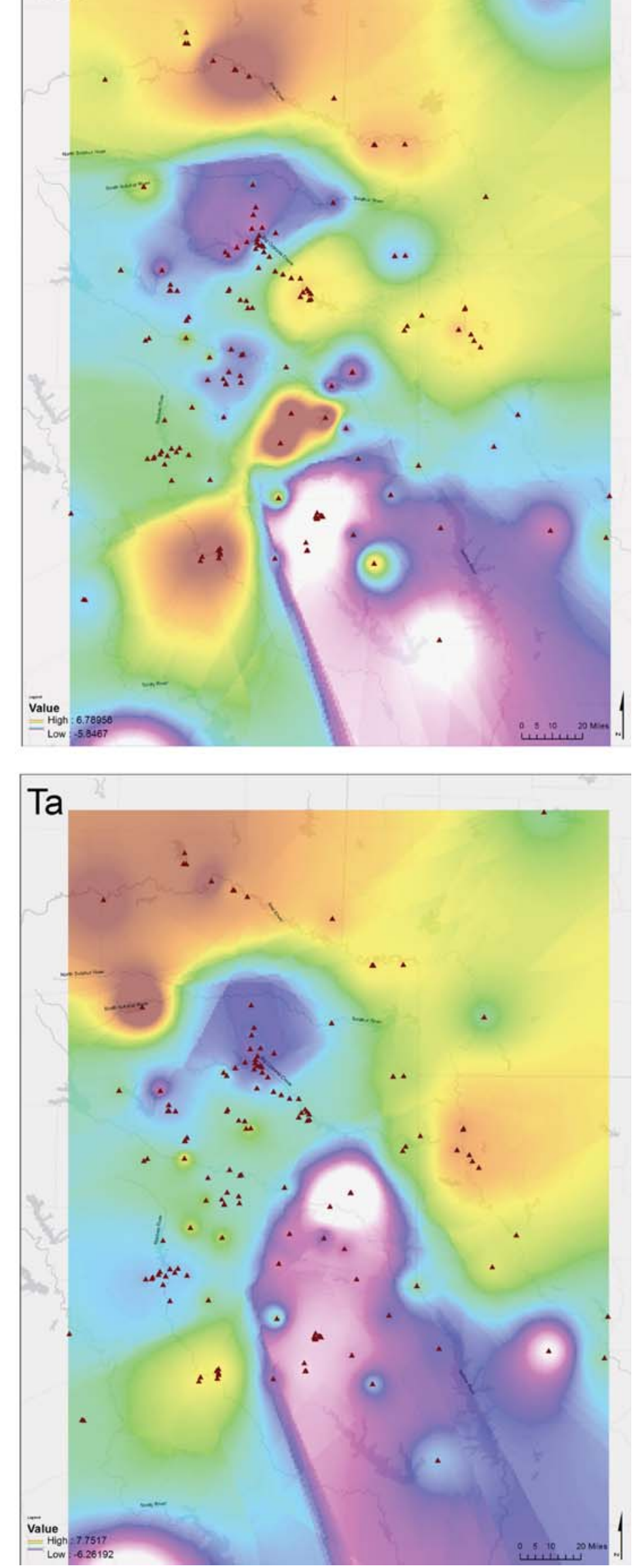

Figure 8. $S c, S m, S r$, and $T a$ presence in data set. 

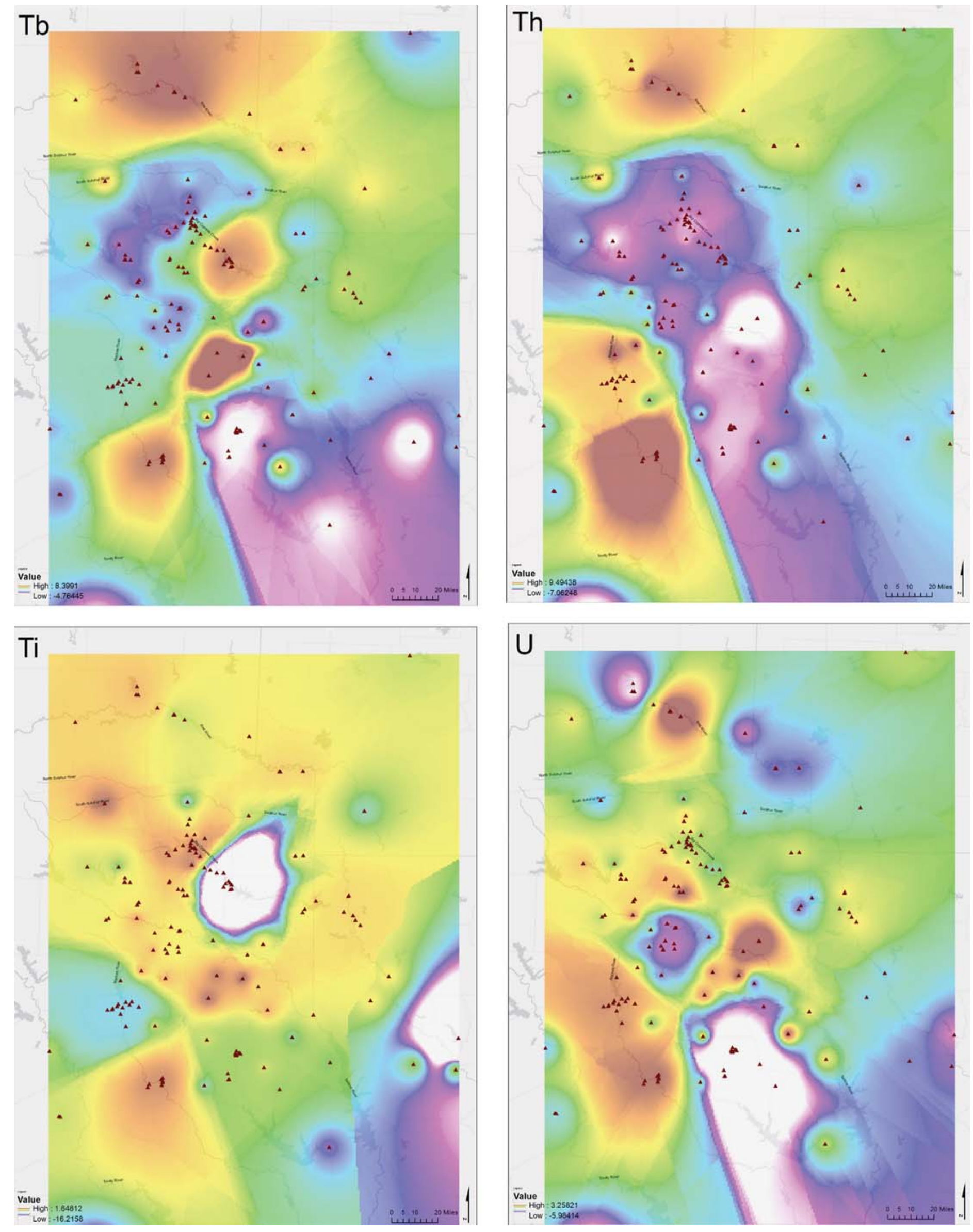

Figure 9. $T b, T h, T i$, and $U$ presence in data set. 

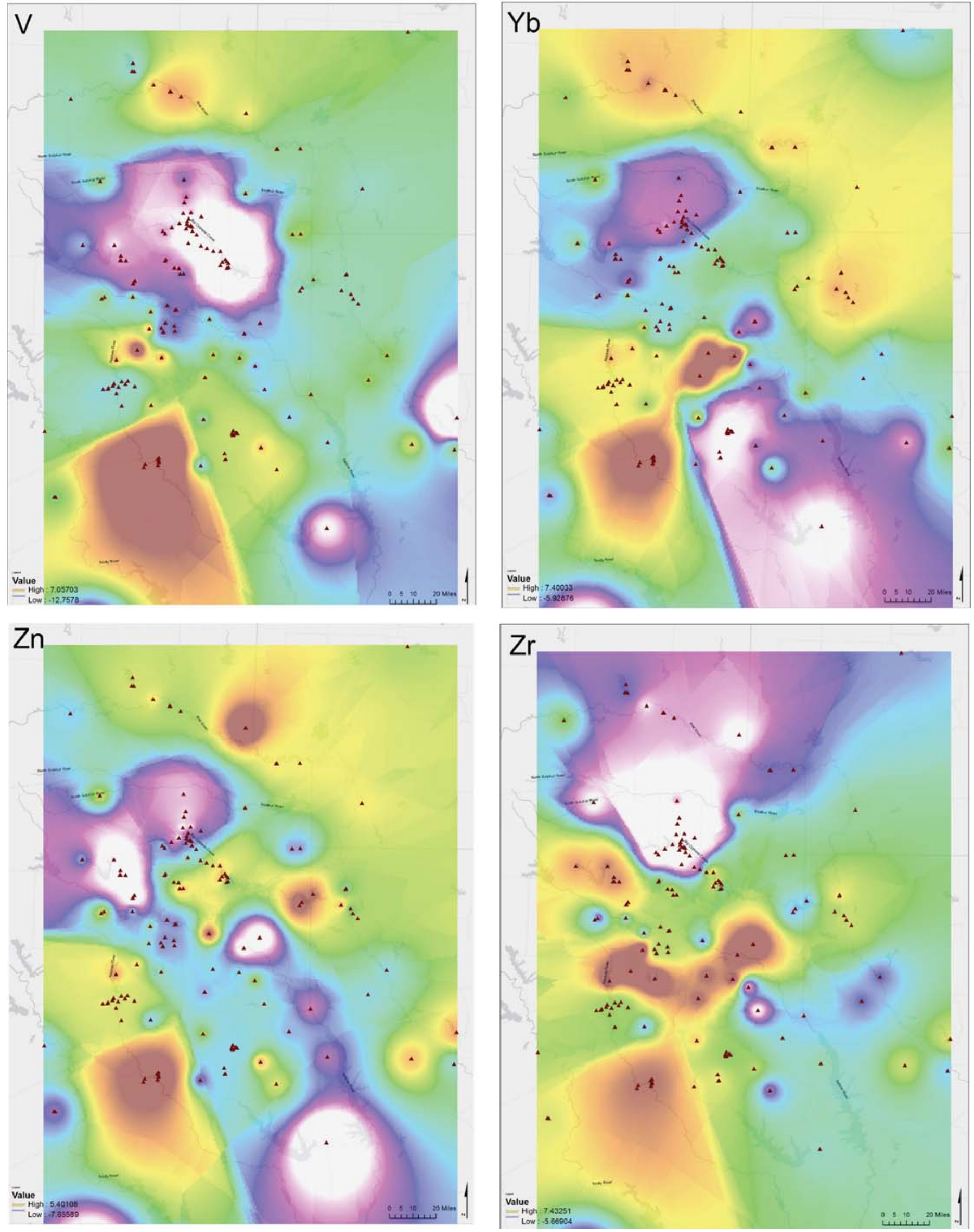

Figure 10. $V, Y b, Z n$, and $Z r$ presence in data set. 


\section{References Cited}

ERSI

2004 ArcGIS9: Using ArcGIS Geostatistical Analyst. ESRI, Redlands, CA.

2012 ESRI Developer Network. Electronic resource, http://edndoc.esri.com/arcobjects/9.2/NET/ shared/geoprocessing/spatial_statistics_tools/hot_spot_analysis_getis_ord_gi_star_spatial_ statistics_htm, accessed November 18, 2012.

Ferguson, J.R.

2010 Preliminary Report on the Reanalysis of the Texas Caddo NAA Database. In Studies on the Instrumental Neutron Activation Analysis of Woodland Period and Caddo Tradition Ceramics from Eastern Texas, compiled by T. K. Perttula, Article 1. Special Publication No. 17. Friends of Northeast Texas Archaeology, Austin and Pittsburg.

Mitchell, A.

2005 The ESRI Guide to GIS Analysis, Volume 2: Spatial Measurements and Statistics. ESRI Press, Redlands, CA.

Steponaitis, V. P., M. J. Blackman and H. Neff

1996 Large-Scale Patterns in the Chemical Composition of Mississippian Pottery. American Antiquity 61(3):555-572. 